\title{
Noziedzīgās rīcības un ar to saistīto jēdzienu interpretācijas problemātika krimināltiesībās
}

\author{
Jānis Baumanis \\ Rīgas Stradiṇa universitāte, Juridiskā fakultāte, \\ Tiesību zinātṇu katedra, Latvija \\ Janis.Baumanis@rsu.lv
}

Kopsavilkums. Krimināllikumā noziedzīgu rīcību apzīmējošo jēdzienu lietošanā ir saskatāmas daudzas nekonsekvences. Pastāv vairāki noziedzīgu aktivitāti vai pasivitāti atspoguḷojoši jēdzieni, kuru klāstā visbiežāk piemin darbību un bezdarbību. Jāuzsver, ka likumdevējs ne vienmēr ir pratis izvēlēties piemērotāko jēdzienu.

Analizējot tematu, autors secina, ka Krimināllikumā nepieciešams pilnveidot tiesību normas, ievērojot šādas prasības: sistēmiskumu, viennozīmīgumu, nozīmes precizitāti un formas īsumu, sinonīmu nevēlamību, neatkarību no konteksta, emocionālu neitralitāti.

Atslēgvārdi: Krimināllikums, noziedzīga rīcība, tiesību normu interpretācija.

Raksta mērḳis ir atklāt noziedzīgās rīcības un ar to saistīto jēdzienu interpretācijas problemātiku un piedāvāt iespējamos risinājumus, lai novērstu tiesību normās konstatētās nepilnības.

Izpētes metodes. Rakstā, analizējot krimināltiesiskās normas, autors identificē pastāvošās interpretācijas problēmas un, balstoties uz identificētām problēmām, sintezē priekšlikumus normu jaunradei.

Eiropas Komisijas paziṇojumā Eiropas Parlamentam, Padomei, Eiropas Ekonomikas un sociālo lietu komitejai un Reǵionu komitejai cẹ̦ā uz Eiropas Savienības kriminālpolitiku "Eiropas Savienības politikas efektīvas īstenošanas nodrošināšana ar krimināltiesību palīdzību" [2] ir sniegts redzējums saskan,otai un konsekventai Eiropas Savienības kriminālpolitikai līdz 2020. gadam, norādot, ka jābūt kopīgai izpratnei par pamatprincipiem, uz kuriem ir balstīti Eiropas Savienības tiesību akti krimināltiesību jomā, piemēram, par Eiropas Savienības krimināltiesībās lietoto juridisko pamatjēdzienu interpretāciju. Lai īstenotu šo uzdevumu, tādējādi panākot krimināltiesisko 
Jānis Baumanis. Noziedzīgās rīcības un ar to saistīto jēdzienu interpretācijas problemātika krimināltiesībās

jēdzienu kopīgo interpretāciju Eiropas Savienības likumdošanas mērogā, nepieciešama krimināltiesību normu, kā arī tajās ietverto jēdzienu vienveidīga interpretācija Eiropas Savienības valstīs. Šajā rakstā autors izklāsta noziedzīgas rīcības un ar to saistīto jēdzienu interpretācijas problemātiku Latvijas krimināltiesībās.

Temata aktualitātes pamatošanai jānorāda, ka Krimināllikumā noziedzīgu rīcību apzīmējošo jēdzienu lietošanā ir saskatāmas daudzas nekonsekvences. Pastāv vairāki noziedzīgu aktivitāti vai pasivitāti atspoguḷojoši jēdzieni, kuru klāstā visbiežāk piemin darbību un bezdarbību, un likumdevējs ne vienmēr ir pratis izvēlēties piemērotāko jēdzienu. Piemēram, Krimināllikuma 13. panta pirmajā dạ̦ā saistībā ar nepieskaitāmību tiek lietots jēdziens "darbība". Šajā normā paredzēts, ka pie kriminālatbildības nav saucama persona, kas nodarījuma izdarǐšanas laikā atradusies nepieskaitāmības stāvoklī, t. i., psihisko traucējumu vai garīgās atpalicības dēl nav varējusi saprast savu darbību vai to vadìt. Burtiski interpretējot šo normu, varētu kḷūdaini šḳist, ka Krimināllikuma 13. panta pirmā daḷa liedz iespēju atbrīvot no kriminālatbildības nepieskaitāmo personu par piel̦auto bezdarbību, jo darbība nav viens un tas pats, kas bezdarbība.

Turpinot noziedzīgo rīcību atspoguḷojošo jēdzienu interpretācijas aktualitātes pamatojumu, jāpievērš uzmanība arī jēdzienam "nodarījums", kas, pēc autora domām, sevī ietver gan darbỉbu, gan bezdarbību, gan sekas, gan arī visas citas noziedzīga nodarỉjuma sastāva pazīmes. Šādu secinājumu autors izdara, jo Krimināllikuma 1. panta pirmajā daḷā nepārprotami tiek norādīts, ka nodarījums ietver visas noziedzīga nodarỉjuma pazìmes. Minētā norma nosaka, ka pie kriminālatbildības saucama un sodāma tikai tāda persona, kura ir vainīga noziedzīga nodarījuma izdarī̌sanā, t. i., kura ar nodomu (tî̌i) vai aiz neuzmanības izdarījusi šajā likumā paredzētu nodarījumu, kam ir visas noziedzịga nodarījuma sastāva pazìmes.

Autora secinājums, ka nodarījums ir ne tikai darbïba vai bezdarbība, bet arī citas noziedzīga nodarījuma sastāva pazīmes, ir pretrunā profesora Ulda Krastiṇa viedoklim. Viṇš savukārt norāda, ka Krimināllikuma 6. panta pirmajā dạ̦ā nepārprotami ir pateikts, ka nodarijums ir darbỉba vai bezdarbïba. Darbïba vai bezdarbỉba par noziedzīgu nodarījumu kḷusst, ja par to likumā paredzēta kriminālatbildība. Kaitīgas sekas krimināltiesībās ir vērtējamas kā noziedzīga nodarījuma objektīvās puses patstāvīga pazìme, ja tās paredzētas konkrēta noziedzīga nodarījuma sastāva pazìmju skaitā [8].

Krimināllikuma 6. panta pirmajā dạ̦ā paredzēts, ka nodarījuma (darbības vai bezdarbības) noziedzīgumu un sodāmību nosaka likums, kas bijis spēkā šā nodarījuma izdarīšanas laikā. Kā redzams, šajā normā nodarījums iekavās tiek skaidrots tikai kā darbība vai bezdarbība. Tādējādi ir acīmredzama nekonsekvence starp Krimināllikuma 1. panta pirmajā dậa lietoto jēdzienu "nodarỉjums" un Krimināllikuma 6. panta pirmajā dạ̣ā lietoto jēdzienu "nodarījums". Iepriekšminēto papildinot, jāatzīst, ka arī krimināltiesību teorijā vērojama nekonsekvence noziedzīgu rīcību apzīmējošo jēdzienu lietošanā. 
Saskaṇā ar krimināltiesību doktrīnā nostiprināto atziṇu "noziedzīgs nodarījums ir personas konkrētas uzvedības akts, tās aktīva, prettiesiska rīcība (darbība) vai pasīva prettiesiska uzvedība (bezdarbïba), ar ko tiek nodarìts vai varējis tikt nodarìts kaitējums ar Krimināllikumu aizsargātām interesēm" [4, 14]. Minētā atziṇa pausta saistībā ar Krimināllikuma 1. panta pirmajā dạ̦ā noteikto. Savukārt saistībā ar Krimināllikuma 6. panta pirmajā dal̦ā sniegto noziedzīga nodarijuma jēdzienu doktrīnā tiek norādīts: "Nodarījums ir personas konkrēta uzvedỉba, kas izpaužas viņas prettiesiskā darbībā vai bezdarbībā (rīcībā)" [4, 38]. Kā redzams, komentējot noziedzīgo darbību un bezdarbību, vienā gadījumā jēdzienu "rīcība" izmanto, lai apzīmētu tikai darbỉbu, bet otrā gadījumā minētais jēdziens ietver sevī gan darbỉbu, gan bezdarbỉbu. Arī jēdziens "uzvedība" vienā gadījumā tiek saistîts tikai ar bezdarbību, bet citā - gan ar bezdarbību, gan ar darbïbu.

N̦emot vērā îsi ieskicēto temata aktualitāti, raksta mērḳis ir atklāt noziedzīgās rīcības un ar to saistīto jēdzienu saturu, identificēt iespējamās minēto jēdzienu interpretācijas problēmas un piedāvāt to risinājumus.

Jāatzīst, ka Krimināllikumā nav definēts jēdziens "noziedzīgā rīcība". Iepazīstoties ar Latviešu valodas vārdnīcā sniegto vārda "rīcība" skaidrojumu, var konstatēt, ka šis vārds tiek skaidrots ar vārdu "darbỉba" $[11,916]$. Arī Latviešu valodas sinonīmu vārdnīcā kā "rīcības" sinonīmi minēti ar darbību saistīti vārdi: "rīkošanās", "izrīcība", "gājiens" un "izdarība" [10, 336].

Jāpiebilst, ka ar vārdu "rīcība" Latviešu valodas vārdnīcā tiek skaidrots vārds "uzvedība" [11, 1139]. Profesors Uldis Krastiņš norāda: "Ar cilvēka uzvedību saprotam abus tās izpausmes veidus - aktīvu darbību un pasīvu darbību jeb bezdarbību" [3]. N̦emot vērā minēto, jāsecina, ka gan vārds "uzvedība", gan vārds "rīcība" apzīmē darbību un bezdarbību.

Meklējot citās tiesību nozarēs jēdziena "rīcība" skaidrojumus, var atrast, ka, piemēram, papildus Administratīvā procesa likuma 89. panta pirmajā dạ̦ā esošai norādei uz iestādes faktisko rīcību kā darbību panta otrajā dạ̦ā skaidrots, ka faktiskā rīcība ir arī iestādes bezdarbība. Arī autors uzskata, ka rīcība ir jēdziens, kas atspoguḷo ne tikai aktivitāti, bet arī pasīvu uzvedību jeb bezdarbību.

Lai jautājums par rīcību kā darbību un bezdarbību apvienojošo jēdzienu nebūtu tikai filosofisks, autors piedāvā analizēt konkrēto Krimināllikuma normu. Proti, Krimināllikuma 189. pantā noteikta kriminālatbildība par tādas personas neapzinīgu un nevērīgu savu pienākumu veikšanu, kurai uzdota mantas apsardzỉba, ja šāda rīcība bijusi par iemeslu šis mantas nolaupišsanai, bojāejai vai bojāšanai lielā apmērā. Lai gan šajā normā noziedzīga nodarījuma objektīvā puse tiek atklāta ar darbības vārdu "veikšana", kam seko vārds "rīcība", autoram šḳiet, ka korektāk nodarījumu raksturotu formulējums "pienākumu neveikšana". Komentējot šo normu, tiek norādīts: "Nodarïjuma prettiesiskums izpaužas pasīvā uzvedībā [..]" [3, 80]. Iepriekš šì norma tika komentēta šādi: "Darbība izpaužas pasīvā uzvedībā. Persona, kurai bijusi uzticēta mantas apsardzība, nepienācīgi veikusi savus pienākumus, piemēram, noliktavas sargs atstājis apsargājamo objektu, sargāšanas laikā gulējis u. tml., kā rezultātā iestājušās panta 
dispozīcijā minētās sekas" [7, 415]. Kā redzams, gulēšana sargāšanas laikā ir darbība, kas, izrādās, ir pienākumu veikšana, vienīgi šì veikšana ir neapzinīga un nevērīga.

Daudz veiksmīgāks un saprotamāks noziedzīga nodarījuma formulējums bija iepriekš spēkā esošajā Latvijas Kriminālkodeksa 146.2 pantā, kurā bija paredzēta kriminālatbildība par personas, kurai uzdota mantas apsardzība, neapzinīgu un nevērīgu izturēšanos pret saviem pienākumiem, ja tā bijusi par iemeslu šās mantas nolaupīšanai, bojāejai vai bojāšanai lielos apmēros un ja nav amatnozieguma pazimju. Komentējot šo normu, tika norādīts: "Nozieguma objektīvā puse izpaužas bezdarbībā, kas normā formulēta kā "neapzinīga un nevērīga izturēšanās pret saviem pienākumiem"” [13, 140]. Latvijas Kriminālkodeksa $146 .{ }^{2}$ pantā formulētā neapzinīgā un nevērīgā izturēšanās pret mantas apsardzību neradīja nekādas šaubas par šā noziedzīgā nodarỉjuma objektīvo pusi, kura izpaudās bezdarbībā. Neraugoties uz spēkā esošās normas neveiksmīgu formulējumu, kas liek secināt, ka mantas neapzinīgā un nevērīgā apsardzība ir darbība, jāatzīst, ka faktiski neapzinīga un nevērīga apsardzība izpaužas tikai un vienīgi bezdarbībā.

Autors atbalsta jēdziena "rīcība" izmantošanu Krimināllikuma 189. pantā, jo rīcība var būt arī bezdarbība, tomēr autors nesaprot, kāpēc tika izvēlēts vārds "veikšana", kas faktiski apzīmē darbību. Tieši neveiksmīgs normas formulējums, pēc autora domām, kḷuva par iemeslu tam, ka doktrīnā minētā noziedzīga nodarījuma objektīvās puses izskaidrošanai sāka lietot vārdu "darbība".

Krimināltiesību doktrīnā jēdzienu "rīcība" autors piedāvā konsekventi lietot kā darbību un bezdarbību apvienojošo jēdzienu. Ja tiek piennemts šis autora piedāvājums, var secināt, ka noziedzīga rīcība ir jebkura noziedzīga nodarījuma objektīvās puses obligātā pazīme, kas var izpausties kā darbībā, tā arī pasīvā uzvedībā jeb bezdarbībā. Turklāt vārds "darbība" neaptver pasīvo uzvedību jeb bezdarbību. Minēto apstiprina Krimināllikumā daudzviet redzamais formulējums, kurā papildus jēdzienam "darbība" pēc vārda "vai" tiek pieminēts jēdziens "bezdarbība". Piemēram, Krimināllikumā gan 5. panta pirmajā daḷā, gan 6. panta pirmajā daḷā, gan 20. panta pirmajā daḷa un daudzās citās normās pēc vārda "darbība" seko vārds "bezdarbība". Šo normu klāstā izceḷas Krimināllikuma 15. panta ceturtā daḷa, kurā vārds "bezdarbība" ielikts iekavās pēc vārda "darbība", kas škietami liek noprast, ka bezdarbïba ir darbïbas veids. Neraugoties uz minēto vienu niansi, tiesiskajā regulējumā un doktrīnā bezdarbība ir nošķirta no darbības. Lai šì nošḳiršana neradītu pārpratumus, likumdevējam vajadzētu būt konsekventam vārda "darbïba" izmantošanā Krimināllikumā.

Prezumējot, ka darbība nav bezdarbība, Krimināllikumā būtu jāpilnveido daudz normu, tostarp 19. panta formulējums, kas šobrīd, skaidrojot dalības būtību, paredz: "Par dalību (līdzizdarīšanu) uzskatāma apzināta noziedzīga darbība, ar kuru tīšu noziedzīgu nodarījumu kopīgi, to apzinoties, tieši izdarījušas divas vai vairākas personas (tas ir, grupa)." Burtiski interpretējot minēto formulējumu, var secināt, ka grupā iespējams izdarìt tikai noziedzīgu darbību. N̦emot vērā minēto, rodas jautājums, kā, piemēram, kvalificēt Krimināllikuma 99. panta ceturtajā daḷā paredzēto atkritumu apsaimniekošanas noteikumu pārkāpšanu, ja to izdarỉjusi organizēta grupa? Komentējot minēto 
Jānis Baumanis. Noziedzīgās rīcības un ar to saistīto jēdzienu interpretācijas problemātika krimināltiesībās

normu, tiek norādīts: "Noziegums izpaužas kā darbība vai bezdarbība, ja ar to pārkāpti atkritumu apsaimniekošanas noteikumi, tostarp atkritumu pārvietošanas noteikumi" [10, 115]. Tātad, ja grupa bezdarbībā pārkāpa noteikumus, vai tad būtu jāatzīst, ka, pamatojoties uz Krimināllikuma 19. pantu, nav konstatējama dalība? Lai nerastos kḷūdainas atziņas, atbildot uz šo jautājumu, autors uzskata, ka Krimināllikuma 19. pantā vārdu "darbība" būtu jāaizstāj ar vārdu "rīcība".

Saistībā ar jēdzienu "noziedzìga darbība" jāmin arī Krimināllikuma 23. panta trešajā daḷā norādītais: "Atsevišçu turpinātu noziedzīgu nodarījumu veido vairākas savstarpēji saistītas tādas pašas noziedzīgas darbïbas, kas vērstas uz kopēju mērḳi, ja tās aptver vainīgās personas vienots nodoms, tāpēc savā kopumā tās veido vienu noziedzīgu nodarījumu." Šāds normas formulējums liek secināt, ka atsevišḳu turpinātu noziedzīgu nodarījumu klāstā var ietilpt tikai noziedzịgas darbības. Pieturoties pie tādas interpretācijas, rodas jautājums, kā kvalificēt, piemēram, Krimināllikuma 219. panta otrajā dạā paredzēto noziedzīgo nodarījumu, kad tas pēc kāda laika tiek turpināts. Proti, minētajā normā ir paredzēta kriminālatbildība par nepatiesu ziṇu norādīšanu likumā noteiktajā ienākumu, îpašuma, darỉjumu vai cita mantiska rakstura deklarācijā, ja nepatiesas ziṇas norādītas par mantu vai citiem ienākumiem lielā apmērā. Ja persona nolēmusi nekad nedeklarēt savu vienu konkrēto mantu lielā apmērā un šo ieceri îstenoja, piemēram, divus gadus pēc kārtas, kam sekoja periods, kad personai nebija jāiesniedz deklarācija un pēc kura persona atkal turpināja nedeklarēt savu vienu konkrēto mantu lielā apmērā, vai tad šo nodarījumu būtu jāatzīst par ilgstošu, neraugoties uz to, ka pastāvēja periods, kad personai nebija jāsniedz deklarācija? Atzīstot to par ilgstošu, tiktu pārkāpta Krimināllikuma 23. panta ceturtā dal̦a, kas paredz, ka atsevišķs ilgstošs noziedzīgs nodarījums ir nepārtraukta viena noziedzīga nodarỉjuma sastāva realizēšana (darbība vai bezdarbïba), kas saistita ar tai sekojošu ilgstošu to pienākumu neizpildīšanu, kurus likums ar kriminālvajāšanas piedraudējumu uzlicis vainīgajai personai. Izklāstītajā piemērā nepārprotami bija norādīts, ka nodarījums nebija nepārtraukts.

Savukārt, ja katru atsevišḳu deklarācijas neiesniegšanas faktu atzīt par patstāvīgu noziedzīgu nodarījumu un tos kopumā kvalificētu kā noziedzīgu nodarījumu daudzējādību, tad tiktu pārkāpta Krimināllikuma 23. panta pirmā dal̦a, kas paredz, ka atsevišḳs (vienots) noziedzīgs nodarījums ir arī divi vai vairāki savstarpēji saistīti noziedzīgi nodarījumi, kurus aptver vainīgās personas vienots nodoms un kuri atbilst tikai viena noziedzīgā nodarījuma sastāva pazìmēm. Izklāstītajā piemērā nepārprotami bija norādīts uz personas vienotu nodomu - nekad nedeklarēt savu konkrēto mantu lielos apmēros.

Lai nerastos norādītie pārpratumi, autors uzskata, ka Krimināllikuma 23. panta trešajā dạ̦ā vārdu "darbība" vajadzētu aizstāt ar vārdu "rīcība".

Pamatojot temata aktualitāti, autors minēja, ka Krimināllikuma 13. panta pirmajā dạ̣a saistībā ar nepieskaitāmību tiek lietots arī vārds "darbība". Lai izslēgtu nepareizu minētās normas interpretācijas iespēju, kuras ietvaros kḷudaini tiktu secināts, ka par pieḷauto noziedzīgo bezdarbību nepieskaitāmo personu var saukt pie 
Jānis Baumanis. Noziedzīgās rīcības un ar to saistīto jēdzienu interpretācijas problemātika krimināltiesībās

kriminālatbildības, autors uzskata, ka korektāk Krimināllikuma 13. pantā vārda "darbība" vietā būtu izmantot vārdu "rīcība", analogiiski kā tas ir izdarīts, piemēram, Krimināllikuma 59. panta piektajā dạ̦ā. Precizitātes labad jāatzīst, ka šajā normā jēdziens "rīcība" netiek attiecināts uz noziedzīgu nodarījumu. Proti, šajā normā noteikts: ja persona, kura notiesāta par noziedzīgu nodarījumu vai kurai sods noteikts ar prokurora priekšrakstu par sodu, pēc sprieduma pasludināšanas vai pēc tam, kad prokurors izdevis priekšrakstu par sodu, saslimusi ar gara slimību, kas tai atñēmusi iespēju saprast savu rīcību vai to vadìt, tiesa atbrīvo šo personu no soda izciešanas.

Krimināllikuma 13. panta pilnveidei arī kā variants ir atzīstams vārda "darbība" aizstāšana ar vārdu "nodarījums". Šāds variants pastāvēja 1933. gada 24. aprīḷa Sodu likumā, kurā 38. pantā bija izmantots gan vārds "nodarījums", gan arī vārds "rīcība”. Proti, minētajā normā bija paredzēts: "Nav pieskaitāms par vainīgu ar soda piedraudējumu noliegts nodarījums, ja to izdarījusi persona, kura, noziedzīgo nodarījumu izdarīdama, aiz slimīga gada darbības traucējuma, vai nesamaņas stāvoklī būdama, vai aiz garīgas neattīstības, kas cēlusies no miesīga trūkuma vai slimības, nav varējusi saprast sava nodarìjuma raksturu un nozīmi vai vadìt savu rīcību" [14].

Iepriekš autors publiski jau bija paudis viedokli, ka jēdziens "nodarïjums" ietver visas noziedzīga nodarījuma pazīmes. Ir absurdi, ka tikai kopā ar vārdu "noziedzīgais" jēdziens "nodarījums" aptver sekas un citas noziedzīga nodarījuma pazīmes. Tādējādi sekas faktiski tiek atzītas par noziedzīga nodarījuma objektīvās puses fakultatīvo pazìmi [13]. Neatkārtojot sava viedokḷa argumentus un aizvien vēl aizstāvot šo viedokli, autors secina, ka rīcība ir gan darbỉba, gan bezdarbỉba, turklāt rīcība kopā ar citām noziedzīga nodarījuma pazīmēm, tai skaitā kopā ar darbības vai bezdarbības sekām, ir nodarījums.

Noziedzīgas rīcības būtîbas skaidrojumam svarīgi izprast šīs rīcības sākuma un beigu brīdi. Krimināltiesībās bieži tiek analizēts brīdis, ar kuru noziedzīgs nodarījums tiek uzskatīts par pabeigtu. Gadījumos, kad noziedzīgs nodarījums ir ar formālu sastāvu, varētu škist, ka noziedzīgās rīcības beigu brīdis sakrīt ar noziedzīga nodarījuma beigu brīdi. Tomēr krimināltiesībās ar pabeigto noziedzīgo nodarījumu saprot nodarījumu, kas ir šķērsojis nepabeigta noziedzīga nodarījuma stadijas, un šis brīdis var arī nesakrist ar faktiski turpināto vai ilgstošo noziedzīgo rīcību.

Saistībā ar noziedzịgas rīcības sākuma un beigu brīdi jāmin Krimināllikuma 56. panta trešajā dạ̦ā izmantotais jēdziens "noziedzīga nodarījuma izdarīšanas brīdis". Proti, minētā norma paredz, kad tiek pārtraukts kriminālatbildības noilgums, norādot: ja persona izdara jaunu noziedzīgu nodarījumu, tad noilguma laiku, kas paredzēts par smagāko no izdarītajiem noziedzīgajiem nodarījumiem, sāk skaitīt no jaunā noziedzīgā nodarījuma izdarǐšanas brīža. Komentējot šo brīdi, teorijā tiek norādīts: "Par noziedzīga nodarījuma izdarǐšanas dienu atzīstama diena, kad izdarīta noziedzīga darbība vai piel̦auta bezdarbība. Atsevišḳa turpināta noziedzīga nodarījuma gadỉjumā tā izdarīšanas diena būs diena, kad izdarīta pēdējā ar vainīgā vienotu nodomu aptverta savstarpēji saistīta tāda pati noziedzīga darbība, kas vērsta uz vienotu mērḳi, bet atsevišḳa ilgstoša noziedzīga nodarījuma gadījumā - diena, kad vainīgā persona izdarījusi nodarỉjumu 
(darbību vai bezdarbību), piemēram, bēgusi no ieslodzījuma vietas neatkarīgi no tā, kad šis noziedzīgais stāvoklis beigsies" [4, 244]. No sniegtā skaidrojuma likumsakarīgi rodas jautājums, kas ir noziedzīgs stāvoklis? Pēc autora domām, bezdarbības gadījumā jēdziens "noziedzīgs stāvoklis" sakrīt ar noziedzīgo rīcību.

Jāmin, ka ilgstošam likumpārkāpumam uzmanība ir pievērsta arī administratīvās atbildības pilnveides kontekstā. Likumprojekta "Administratīvo pārkāpumu procesa likums" sākotnējās ietekmes novērtējuma ziṇojumā (anotācijā) tiek norādīts, ka praktiska rakstura problēma ir iestāžu tālākās rīcības iespējas gadījumos, kad persona pat pēc soda piemērošanas nepārtrauc ilgstošu pārkāpumu. Daudzos gadījumos pārkāpuma turpināšana ne tikai norāda uz personas nihilistisku attieksmi pret likumu, bet arī ir sabiedriski kaitīga un bīstama. Tomēr likums šobrīd skaidri nenosaka, kādas ir iestādes iespējas šādu personu sodīt atkārtoti par administratīvā pārkāpuma turpināšanu. N̦emot vērā minēto, likumprojekts paredz iespēju atkārtoti administratīvi sodīt ilgstoša administratīvā pārkāpuma gadỉjumā. Tas paredz, ka personu var atkārtoti sodìt, ja tā nepilda savu tiesisko pienākumu - nepārtrauc administratīvo pārkāpumu. Lai personai tiktu piemērota atkārtota administratīvā sodīšana ilgstoša administratīvā pārkāpuma gadījumā, ir šādi pamatkritēriji: 1) sākotnējā soda piemērošana, 2) personas informatīva brīdināšana par pienākumu pārtraukt (novērst) pārkāpumu saprātīgā laikā, 3) personas bezdarbība, kas izpaužas kā ar likumu noteiktā pienākuma neizpilde [12].

N̦emot vērā administratīvās atbildības pilnveides procesā izdarìtos secinājumus, būtu jāpakḷauj izvērtēšanai, vai par ilgstoša noziedzīga nodarỉjuma beigu brīdi nevajadzētu atzìt faktisko noziedzīga nodarījuma pārtraukšanas laiku, respektīii, brīdi, kad personas rīcībā nav noziedzīga nodarījuma objektīvās puses pazīmju.

Arī jautājums par noziedzīgas rīcības sākuma brīdi nav viegli atbildams. Krimināllikuma 16. panta pirmajā dạā norādīts, ka labprātīga atteikšanās no noziedzīga nodarījuma izdarīšanas ir personas uzsāktā noziedzīgā nodarỉjuma pilnīga pārtraukšana pēc šīs personas gribas, tai apzinoties, ka pastāv iespēja noziedzīgo nodarījumu izdarīt līdz galam. No minētās normas izriet, ka gatavošanas un mēǵinājuma stadijā noziedzīgais nodarijums ir jau uzsākts. Tajā pašā laikā Krimināllikuma 20. panta devītajā dạ̦ā noteikts, ka organizētāja un uzkūdītāja labprātīga atteikšanās no noziedzīgā nodarījuma izdarī̌sanas līdz galam uzskatāma par tādu tikai tajos gadījumos, kad viṇi savlaicīgi darījuši visu iespējamo, lai novērstu ar viṇu lïdzdalību iecerētā noziedzīgā nodarījuma izdarīšanu, un šis nodarījums nav izdarīts. Normas turpinājumā norādīts, ka atbalstītājs nav saucams pie kriminālatbildības, ja viṇš līdz noziedzīgā nodarījuma uzsākšanai labprātīgi atteicies sniegt apsolìto palīdzību.

Kā redzams, uz līdzdalībniekiem labprātīgās atteikšanās institūts attiecas līdz brīdim, kad noziedzīgs nodarījums vēl nav uzsākts, savukārt uz noziedzīga nodarījuma izdarītāju labprātīgās atteikšanās institūts darbojas pēc noziedzīga nodarījuma uzsākšanas.

Redzot Krimināllikuma 16. panta pirmās dal̦as formulējumu, kurā ar uzsākto noziedzīgo nodarījumu tiek apzīmēta arī gatavošanās noziedzīgam nodarījumam, 
Jānis Baumanis. Noziedzīgās rīcības un ar to saistīto jēdzienu interpretācijas problemātika krimināltiesībās

kā arī, redzot Krimināllikuma 20. panta devītās daḷas formulējumu, kurā lietots jēdziens "līdz noziedzīga nodarījuma uzsākšanai", ir ḷoti sarežg̀iti atrisināt situāciju, kurā atbalstītājs ar izdarītāju labprātīgi atsakās no noziedzīga nodarījuma izdarǐšanas tā gatavošanas stadijā.

Apzinoties, ka rakstā nav sniegtas atbildes uz visiem jautājumiem, kas saistīti ar noziedzīgu rīcību apzīmējošo jēdzienu interpretāciju, autors nobeigumā citē normatīvo aktu izstrādes rokasgrāmatā norādīto: "Lai termins pēc iespējas precīzāk izteiktu jēdzienu, tā izvēlē vai darināšanā ievēro šādas galvenās prasības: sistēmiskumu, viennozīmīgumu, nozīmes precizitāti un formas ìsumu, sinonīmu nevēlamību, neatkarību no konteksta, emocionālo neitralitāti" [9, 24]. Kā redzams no rakstā sniegtajiem piemēriem, izṇemot emocionālo neitralitāti, pārējās prasības Krimināllikuma teksta radī̌̌anā nav pilnībā ievērotas.

\section{Problems of Interpretation of Criminal Activity and Related Notions in the Criminal Law}

\section{Abstract}

Numerous non-consequences are evident in using notions designating criminal activity in the criminal law. If several notions reflecting criminal activity or passivity, which most often mention activity or non-activity, exist, a lawmaker is not always able to select the notion, which would be most suitable.

Covering the topic, the author concludes that legal norms of the criminal law should be improved, observing the following requirements: consistency, non-ambiguity, exact meanings and laconic forms, undesirable synonyms, context independence, emotional neutrality.

Keywords: Criminal Law, Criminal Activity, the interpretation of legal norms.

\section{Literatūra}

1. Baumanis, J. Ieskats krimināltiesību normu interpretācijas problemātikā. Jurista Vārds. 01.09.2015., Nr. 34 (886).

2. Communication from the Commission to the European Parliament, the Council, the European Economic and Social Committee and the Committee of the Regions towards an EU criminal policy: Ensuring the effective implementation of EU policies through criminal law. Brussels, 20.09.2011 COM(2011) 573 final. Iegūts no: http://ec.europa.eu/justice/criminal/ files/act_en.pdf

3. Krastiňš, U. Darbības un bezdarbības izpratne krimināltiesībās. Jurista Vārds. 21.04.2015., Nr. 16 (868).

4. Krastin̦š, U., Liholaja, V. Krimināllikuma komentāri. Pirmā daḷa (I-VIII ${ }^{1}$ nodaḷa). Rīga: Tiesu namu aǵentūra, 2015. 
Jānis Baumanis. Noziedzīgās rīcības un ar to saistīto jēdzienu interpretācijas problemātika krimināltiesībās

5. Krastiņš, U., Liholaja, V. Krimināllikuma komentāri. Otrā daḷa (IX-XVII nodaḷa). Rīga: Tiesu namu aǵentūra, 2016.

6. Krastiņš, U., Liholaja, V., Hamkova, D. Krimināllikuma komentāri. Trešā daḷa (XVII-XXV nodaḷa). Rīga: Tiesu namu aǵentūra, 2016.

7. Krastiņšs, U., Liholaja, V., Niedre, A. Krimināltiesības. Sevišķā daḷa. Trešais papildinātais izdevums. Rīga: Tiesu namu aǵentūra, 2009.

8. Krastinšs, U. Vērtējuma jēdzieni Krimināllikuma normās. Jurista Vārds. 12.06.2012., Nr. 24 (723).

9. Krūmiņa, V., Skujiṇa, V. Normatìvo aktu izstrādes rokasgrāmata. Rīga: Valsts kanceleja, 2002.

10. Latviešu valodas sinonìmu värdnīca. E. Grinberga, O. Kalnciems, G. Lukstin̦š, J. Ozols, A. Pārupe, E. Rauhvagers. Trešais papildinātais un pārstrādātais izdevums. Rīga: Avots, 2002.

11. Latviešu valodas vārdnīca. 30000 pamatvārdu un to skaidrojumi. Atb. red. D. Guḷevska. Rīga: Avots, 2006.

12. Likumprojekta "Administratìvo pārkāpumu procesa likums" sākotnējās ietekmes novērtējuma ziṇojums (anotācija). Iegūts no: http://titania.saeima.lv/LIVS11/saeimalivs11.nsf/0/C09FFF1B 23A17044C2257CDF0023B6DA?OpenDocument\#b\#a

13. Mežulis, D. İpašuma krimināltiesiskā aizsardzība. Rīga: Jumava, 1997.

14. 1933. gada 24. aprīḷa Sodu likums ar likumdošanas motīviem un sīkiem komentāriem, kā arī ar alfabētisko un citiem rādītājiem. Rìga, 1934. Iegūts no: https://dspace.lu.lv/dspace/ handle/7/1283 